\title{
Innovating European Defence
}

\author{
Simon J. Smith
}

\section{Introduction:}

If war is inherently a social act, the same must be said of military innovation. Even narrowing down the key terms and definitions reveals this. The subject of this chapter is the innovation of European defence but the literature on military change has been referred to as 'revolution' (as in the Revolution in Military Affairs), 'transformation' (as in military, martial or force transformation), 'innovation', 'adaptation' and 'change in military praxis' (see Grissom, 2006).

Traditionally, the literature on military innovation was understood to be more the discipline of History and Military Studies than a Social Science per se. According to Grissom (Grissom, 2006: 906), this early literature was formed of 'grand historical narratives, operational histories, or bureaucratic-political case studies'. That is until the publication of The Sources of Military Doctrine by Barry Posen in 1984 (Posen, 1984). Posen stands out for bringing a social scientific approach to the study of military innovation, but is representative of only one school of thought on how militaries innovate. Since then, there has been a flourishing literature that is informed by both the disciplines of History and the Social Sciences.

Stephen Rosen has defined major innovation in defence organizations as 'a change that forces one of the primary combat arms of a service to change its concepts of operation and its relation to other combat arms, and to abandon or downgrade traditional missions' (Rosen, 1988: 134). This definition is appropriate because it allows us to understand innovation in terms of material, ideational and operational indicators of change. Since the end of the Cold War, military organizations in Europe have faced significant reductions in both budgets and manpower while many have also been conducting martial operations either independently or through collective security organizations such as the EU or NATO. In short, European militaries have been asked to do more with less which, in turn, necessitates some form of innovation. The aim of this chapter is to understand the various ways defence forces in Europe have innovated to accommodate this confluence of factors. The chapter addresses military innovation by first looking at historical, geopolitical and strategic contextual trends. The chapter will then outline some of the key conceptual ways that scholars have sought to theorise drivers of innovation in military organizations more generally. Finally, we will apply these concepts to specific cases in order to illuminate the varied and particular approaches to innovation that European militaries have incorporated to meet their material, ideational and operational challenges.

\section{Military Innovation and the Traditional Approach: key lessons from History}

This section illustrates some of the central themes and motivating questions that have been central to the more 'grand historical narratives' approach to understanding military innovation. It will demonstrate the ways in which key historical events - in particular large-scale wars have shaped the thinking of military strategists and organisations when it comes to how they prepare, respond and generally attempt to innovate before and after these events. It will also demonstrate how scholars and theorists have come to understand the central questions and challenges that face military organisations in terms of innovation in response to socio-political, resource, and organisational concerns. Table 1 offers a comprehensive (but not necessarily 
exhaustive or mutually exclusive) indication of the challenges and questions facing modern military forces and their prospects for innovation that are considered in this chapter.

Table 1: Types of Questions Driving Military Innovation

\section{Socio-political Based Questions:}

To have democratic-political oversight of armed forces?

What is the military for and what is the extent and range of tasks it is expected to perform? To pursue nuclear forces or remain conventional only?

All-volunteer forces versus conscription?

The role of women in the armed forces?

What degree (if any) do alliances play in a military strategy?

How much to spend as a percentage of GDP on armed forces?

To what degree will AFs participate in frontline high-intensity tactics and operations?

What ratio between territorial defence and expeditionary forces?

To what degree should the military be integrated with another state's or an International Organisation's military decision-making, command and operational structures?

\section{Economic and Resource Based Questions:}

Full-spectrum force versus specialisation?

How much to spend on new capability development and $R \& D$ versus only maintaining current force posture?

What is your Defence Industrial Strategy?

To buy military capabilities off-the shelf, develop and procure from domestic defence industry or pursue multinational military development and procurement programmes - or some mixture of these options?

How to prioritise quantity versus quality of military capability?

\section{Organisational Based Questions:}

Size of regular forces versus dependency on reserves?

What ratio between land, air and sea force structure (now also cyber and space)?

The ratio of prioritization between preparedness, doctrine and capabilities for conventional warfighting (e.g. Fighting Near-Peer Adversaries) and/or irregular warfighting (e.g. coin)?

To prioritise manoeuvre or attrition when preparing for future war?

How will technology and military capabilities shape the character of war?

To what extent will your forces be interoperable with allies?

What percentage of your force will be earmarked for bi-lateral or multilateral military operations or peace-keeping missions?

How to prioritise risk versus force protection?

A central concern of military strategists and organisations has always been attempting to understand the character (not the nature) of the next war. According to Clausewitz, the famous Prussian military strategist war's nature does not change but its character often does (Clausewitz, 1997: 22). As Christopher Mewett (2014) has explained, the nature of war relates to its 'unchanging essence' or, 'those things that differentiate war (as a type of phenomenon) from other things'. Thus, the nature of war is 'violent, interactive, and fundamentally political'. However, the 'character of war describes the changing way that war as a phenomenon manifests in the real world' (Mewett, 2014). Logically, our focus must be skewed towards the character of warfare as our concern is the processes and drivers of military innovation. How and why militaries change, adapt and transform in order to be fit for (some) purpose - 
traditionally that of wining wars. This chapter will consider how militaries - specifically European militaries - innovate in terms of both theory and practice.

In terms of traditional approaches to innovation, thinkers tended to address this question according to strict interpretations of Defence and Military Studies. In other words, the focus was primarily on the study of military tactics, operations and strategy, the outcome of large scale wars and any lessons-learned that could be gained. For example, they may consider if the next war (i.e. a war that may have to be fought) is likely to be dominated by defence or offence, often referred to as manoeuvre or attrition. A separate but related issue is the impact of technology and military capabilities for shaping the character of the next war. The First World War is often, as we will see below, understood as a classic example of when military strategists got things wrong - and devastatingly so - but as this section demonstrates, military strategists quite often get it wrong. A few key historical examples help to illustrate this.

In the current age, conflict is often described with terms such as irregular or hybrid warfare and fought in grey zones. But the traditional understanding of regular warfare is something that takes place between the identifiable militaries of states (usually great powers) and with finite conclusions. Of course, these are generalities and historians are always keen to point this out. Yet, before major wars, there is always a lot of uncertainty about what the next war will look like and how the combination of capabilities, technology and doctrine will impact on the tangible character of the conflict that transpires.

The accepted thinking before the First World War was that a combination of speed - due to industrialisation and advances in technology leading to an increased lethality of weapons would mean this next war would be deadly, mobile, offensive and short. Deadly as it may have been, the war was in fact a slow, bogged-down war of attrition. Military planners fundamentally misunderstood the impact of those weapons they believed to be offensive (machineguns and artillery) which turned out to be much more suited towards defensive tactics and operations. Therefore, a central concern that emerged from the Great War - and one that focused the minds of strategist and innovators alike during the inter-war period - was how to burst the tyranny of defence. Wartime is a critical driver of innovation by necessity but strategists also try to use times of peace to learn key lessons from the past to innovate their forces, capabilities and doctrine.

This leads to another key theme emanating from the traditional approaches to military innovation: innovators and planners usually draw different lessons from the study of previous wars. In the inter-war period, strategists from all the great powers did exactly this. The conclusion that the French Army drew form the First World War was to further strengthen strategies of defence, ultimately resulting in the Maginot Line. The German answer was to prioritise combined-arms with speed and mobility by innovating and refining their use of capabilities and doctrine towards blitzkrieg. During the same period, but not simultaneously, factions arose in both the US (within the Army Air Corp) and the United Kingdom (the RAF) that looked to airpower for strategic answers on how to win wars. In short, military thinkers and strategists often prepare for the last (or wrong) war. Moreover, war and the perceived threat of war causes competition for ideas with regard the most prudent ways for militaries to innovate.

Interestingly, capabilities were generally advancing in line with technological progress for all the great military powers. The difference was how the various military organisations chose to employ those capabilities. Michael Horowitz (2010: 7) has termed this 'adoption capacity 
theory' or the match between the financial and organizational requirements for adopting a new type of military innovation and the capabilities that a particular country might have. All the great powers were developing advanced (for the time) prototypes of submarines, aircraft and armoured fighting vehicles but the missions they assigned those capabilities and the doctrine they applied were distinctive and tailored to their own lessons-learned.

Before we turn to the next section, two more themes that developed out of the more traditional approaches are insightful with regard to innovation more broadly. The first is that advocates of innovation often oversell (at least initially) the strategic impact of their proposed innovation. During the Second World War, both the examples of blitzkrieg and strategic airpower help to reinforce this concept. Although blitzkrieg was a highly successful military tactic, this lethal combination of combined arms and manoeuvre was not enough to translate into a strategic victory on either the Western or Eastern fronts. Moreover, Germany's adversaries were eventually able to learn and adopt these tactics as well, demonstrating again that innovation tends to happen most rapidly during war. In the case of strategic airpower, early attempts to innovate and apply these tactics were not met with the success rates that the first US Army Air Corps' advocates like Edgar Gorrell, Thomas Milling, William "Billy" Mitchell, and William

Sherman had envisioned or asserted before the start of the war. All of this points to one final theme - certain factions of innovation may fight over the best tactics, operations and strategies but it is war that ultimately decides.

\section{Military Innovation and the Social Sciences: theorizing innovation}

The study of military innovation began to take on a more social-scientific approach in the 1980s with the publication of The Sources of Military Doctrine. Yet the literature has advanced and broadened considerably since then. Terriff et al. (2010: 7) have distinguished 'three main factors that shape the trajectory of military innovation: threat, civil-military relations and military culture'. This section aims to distinguish the various strands in this literature and to identify the key theoretical assumptions attached to each (see Table 2 below). But before this can be achieved, it is important to put forth a general definition of military innovation. Stephen Rosen has defined major innovation in defence organizations as 'a change that forces one of the primary combat arms of a service to change its concepts of operation and its relation to other combat arms, and to abandon or downgrade traditional missions' (Rosen, 1988: 134).

Building on Rosen, Grissom (2006: 907) offers a definition whereby three elements constitute a tacit definition of military innovation.

(1) an innovation changes the manner in which military formations function in the field. Measures that are administrative or bureaucratic in nature, such as acquisition reform, are not considered legitimate innovation unless a clear link can be drawn to operational praxis.

(2) an innovation is significant in scope and impact. Minor reforms or those that have had ambiguous effects on a military organization are excluded, implying a consequentialist understanding of military innovation.

(3) innovation is tacitly equated with greater military effectiveness. Only reforms that produce greater military effectiveness are studied as innovations, and few would consider studying counterproductive policies as innovations. 
This definition approximates to 'a change in operational praxis that produces a significant increase in military effectiveness as measured by battlefield results' (Grissom, 2006). Some literature makes distinctions between 'sustaining innovation' and disruptive innovation' (Farrell et al., 2013: 8). As described in their significant volume Transforming Military Power since the Cold War, 'sustaining innovation' seeks to 'improve on traditionally valued ways of war'. The latter is an innovation that seeks to improve 'undervalued ways of war, or to develop wholly new ways of war'. They also note that 'disruptive innovation' is a more sizable challenge than 'sustaining innovation' due to the necessary changes in 'vested organizational interests' and 'dominant organizational ideas about war' (Farrell et al., 2013: 8). Taken together, this description allows us to understand innovation as material, ideational and operational indicators of change. But we must also ask, how and from where do these changes originate? Is innovation driven by exogenous or endogenous dynamics or some mixture of both? To do this, let us now turn to the major schools of military innovation.

The first is that most identified with the work of Barry Posen, the civil-military model of military innovation. Posen's (1984) work also investigated the key interwar doctrinal developments by the German, British and French armed forces as alluded to in the section above. However, his analysis focused on a critical explanatory variable - the dynamics of civilmilitary relations. He argued that this civil-military dynamic is achieved through a response to perceived external threats which, in turn, determine if and how militaries innovate. According to Posen, innovation succeeds when statesmen 'intervene in military service doctrinal development' and ideally with the support of 'maverick officers'. Furthermore, if militaries fail to innovate, they will 'gradually stagnate and ultimately fail the societies they exist to serve' (Grissom, 2006: 909; Posen, 1984: 222-236). Clearly, in this model innovation is derived from exogenous factors and follows a top-down logic. This model recognises military innovation as critically dependent on the influence and manoeuvring of political/civilian leadership to orchestrate change. This does include interaction between the civil-military leadership but the former retain dominance via their access to and control of resources and other forms of civil authority.

Resources as an external driver of change are also at the centre of the interservice model of military innovation (for example, see: Sapolsky, 1972, 2000; Bacevich, 1986; Cote, 1998). Within this understanding, it is not the dynamic between the civilian and military branches per $s e$ - which does still exist - but the resulting competition between the distinct service-branches of the military for resources (normally in a resource-scare environment) that is the primary driver of innovation. To rephrase Rosen's definition above: a primary combat arm of a service will change its concept of operations and its relation to other combat arms, and abandons or downgrade traditional missions - while competing for resources in pursuit of other concepts, missions and capabilities to stay relevant. In short, the processes here are still externally driven, highly political but overwhelmingly bureaucratic due to a mixture of high reticence towards change and the interservice component of resource competition.

The intraservice model of military innovation changes the focus from interservice to intraservice competition and specifically 'competition between branches of the same military service' (Grissom, 2006: 913). Peter Rosen (1991) has been a primary thinker in this understanding of innovation. He postulates that service are not static unitary actors. In fact, they produce internal actors who 'advocate' innovation in pursuit of 'a new theory of victory, an explanation of what the next war will look like and how officers must fight if it is to be won' (Rosen, 1991: 20). As Grissom explains, 'innovation in modern military organizations tends to 
involve competition between established branches of a military service and new branches that embrace new military capabilities' (Grissom, 2006: 913). Again, we can see a connection to the approaches in the previous section: aircraft carrier innovation over the battleship (Royal Navy) or strategic bombing innovation over airpower seen only as tactical ground support (US Army Air Corp). Critical to innovation under this approach is the establishment of 'a new arm or branch of service and opening the senior officer echelons to officers from the new arm' (Grissom, 2006: 914).

Terry Terriff, Frans Osinga and, most notably Theo Farrell have been critical to the development of a forth strand in the literature - the Cultural Model of Military Innovation. In the work The Sources of Military Change: Culture, Politics, Technology, Farrell recognizes culture to be 'intersubjective beliefs about the social and natural world that define actors, their situations, and the possibilities of action' (Farrell and Terriff, 2001). This, he argues, is a significant driver of military innovation. In their contribution, A Transformation Gap? American Innovation and European Military Change, the authors offer the concept of military culture as a vital 'shaping factor' (Terriff et al., 2010: 8). Military Culture encapsulates those 'identities, norms and values' whereby military organisations internalise their 'role and function' in response to their understanding of their external security environment (Terriff et al., 2010: 8).

What is significant, is that military culture can actually transpire into a 'brake on innovation' due to its reflection of inherent biases derived from those very identities, norms and values. As Joseph Schumpeter has argued (in Sapolsky, 2000: 35), resistance to change in organisations is expected given that there are winners and losers to any change. Innovation, he argues, 'is a process of creative destruction. The new kills off the old' (Schumpeter in Sapolsky, 2000: 35). But unlike Posen who argues military innovation comes from the outside, this brake can only be overcome by a credible military 'leader with authority' to advocate for the necessary cultural change. If this is a direct challenge to a military organisation's 'core identity, it is still likely to be problematic (Terriff et al., 2010: 8). As Farrell and Terriff (2010: 9) understand it:

Innovation that goes against organizational identity usually requires some external shock to military culture, such as defeat in war, in order to jolt the military into a fundamental rethink of its purpose and core business'.

Before moving to the next section, following table gives an overview of the key theoretical schools of military innovation studies as well as some key empirical examples and leading scholars within the various conceptual strands of the literature.

Table 2: Theories of Military Innovation

\begin{tabular}{|l|l|l|l|}
\hline $\begin{array}{l}\text { Model of Military } \\
\text { Innovation }\end{array}$ & $\begin{array}{l}\text { Key Theoretical } \\
\text { Assumptions of the } \\
\text { Model }\end{array}$ & $\begin{array}{l}\text { Empirical } \\
\text { Examples }\end{array}$ & Key Authors \\
\hline $\begin{array}{l}\text { The Civil-Military } \\
\text { Model of Military } \\
\text { Innovation: }\end{array}$ & $\begin{array}{l}\text { Civil-military } \\
\text { dynamics in } \\
\text { response to } \\
\text { perceived external } \\
\text { threats }\end{array}$ & $\begin{array}{l}\text { Key interwar } \\
\text { doctrinal } \\
\text { developments by the } \\
\text { German, British and } \\
\text { French armed } \\
\text { forces. }\end{array}$ & $\begin{array}{l}\text { Barry Posen, B., } \\
\text { Kimberly M. Zisk } \\
\text { Edmund Beard } \\
\text { Deborah Avant }\end{array}$ \\
\hline
\end{tabular}




\begin{tabular}{|c|c|c|c|}
\hline & $\begin{array}{l}\text { determine if and } \\
\text { how militaries } \\
\text { innovate (Grissom, } \\
\text { 2006: 908). }\end{array}$ & & \\
\hline $\begin{array}{l}\text { The Interservice } \\
\text { Model of Military } \\
\text { Innovation: }\end{array}$ & $\begin{array}{l}\text { Resource scarcity is } \\
\text { a key catalyst for } \\
\text { innovation. Military } \\
\text { organizations seek } \\
\text { to maintain their } \\
\text { budget } \\
\text { authority and end- } \\
\text { strength, which } \\
\text { requires them to } \\
\text { maintain control } \\
\text { over their traditional } \\
\text { missions. This } \\
\text { model posits that } \\
\text { services will } \\
\text { compete to develop } \\
\text { capabilities to } \\
\text { address these } \\
\text { contested mission } \\
\text { areas, believing that } \\
\text { additional resources } \\
\text { will accrue to the } \\
\text { winner. The result is } \\
\text { innovation } \\
\text { (Grissom, 2006: } \\
\text { 910). }\end{array}$ & $\begin{array}{l}\text { Development of the } \\
\text { Polaris submarine- } \\
\text { launched ballistic } \\
\text { missile system. } \\
\text { The development of } \\
\text { the A-10 Warthog } \\
\text { and the 'Close Air } \\
\text { Support Debate'. }\end{array}$ & $\begin{array}{l}\text { Harvey M. Sapolsky } \\
\text { Douglas N. Campbell } \\
\text { Michael Armacost } \\
\text { Owen Cote } \\
\text { Andrew Bacevich }\end{array}$ \\
\hline $\begin{array}{l}\text { The Intraservice } \\
\text { Model of Military } \\
\text { Innovation: }\end{array}$ & $\begin{array}{l}\text { Military services } \\
\text { should not be treated } \\
\text { as unitary actors. } \\
\text { Instead, innovation } \\
\text { in modern military } \\
\text { organizations } \\
\text { tends to involve } \\
\text { competition between } \\
\text { established branches } \\
\text { of a military } \\
\text { service and new } \\
\text { branches that } \\
\text { embrace new } \\
\text { military capabilities. } \\
\text { The innovation } \\
\text { process begins when } \\
\text { senior officers } \\
\text { develop 'a new } \\
\text { theory of }\end{array}$ & $\begin{array}{l}\text { US Department of } \\
\text { Defense created } \\
\text { innovative new } \\
\text { special operations } \\
\text { capabilities during } \\
\text { the 1980s by } \\
\text { managing } \\
\text { intraservice politics. } \\
\text { The development of } \\
\text { the Tomahawk } \\
\text { cruise missile. } \\
\text { The development of } \\
\text { the M2 Bradley } \\
\text { infantry fighting } \\
\text { vehicle. }\end{array}$ & $\begin{array}{l}\text { Stephen P. Rosen, } \\
\text { Jon F. Giese } \\
\text { Susan L. Marquis } \\
\text { Vincent Davis }\end{array}$ \\
\hline
\end{tabular}




\begin{tabular}{|c|c|c|c|}
\hline & $\begin{array}{l}\text { victory, an } \\
\text { explanation of what } \\
\text { the next war will } \\
\text { look like and how } \\
\text { officers must fight if } \\
\text { it is to be won'. An } \\
\text { 'ideological } \\
\text { struggle' ensues } \\
\text { within the service. } \\
\text { Advocates of the } \\
\text { new theory work } \\
\text { within the service } \\
\text { to find allies and } \\
\text { resources (Grissom, } \\
\text { 2006: 913) }\end{array}$ & & \\
\hline $\begin{array}{l}\text { The Cultural Model } \\
\text { of Military } \\
\text { Innovation: }\end{array}$ & $\begin{array}{l}\text { Culture (defined as } \\
\text { 'intersubjective } \\
\text { beliefs about the } \\
\text { social and natural } \\
\text { word that define } \\
\text { actors, their } \\
\text { situations, and the } \\
\text { possibilities of } \\
\text { action') is a major } \\
\text { causal factor } \\
\text { in military } \\
\text { innovation. culture } \\
\text { sets the context for } \\
\text { military } \\
\text { innovation, } \\
\text { fundamentally } \\
\text { shaping } \\
\text { organizations' } \\
\text { reactions to } \\
\text { technological } \\
\text { and strategic } \\
\text { opportunities } \\
\text { (Grissom, 2006: } \\
916 \text { ). }\end{array}$ & $\begin{array}{l}\text { The development of } \\
\text { French and British } \\
\text { doctrine between the } \\
\text { World Wars. } \\
\text { The relationship } \\
\text { between } \\
\text { professional military } \\
\text { education and the } \\
\text { professional culture } \\
\text { of a military } \\
\text { organization. }\end{array}$ & $\begin{array}{l}\text { Theo G. Farrell } \\
\text { Terry Terriff } \\
\text { Robert E. Mullins } \\
\text { Emily O. Goldman }\end{array}$ \\
\hline
\end{tabular}

\section{Innovating European Defence}

Given the strands of literature outlined in the previous section, how can we then apply this to the case of Europe specifically? What is needed is an analytical framework that would allow us to cut across these literatures of transformation to provide some meaningful understanding around the specificity of innovation regarding European militaries. In short, what are the implied drivers of innovation?

The first is that militaries are being used beyond their traditional Cold War remits of national 
and regional defence towards counter-insurgency (COIN), peacekeeping, counter piracy, counter terrorism, cyber security and more. In line with Posen's argument, this change is a response to the changing strategic context in which militaries find themselves. The second driver is budgets, or rather, how much and in what way are governments paying for their militaries. Like Sapolsky (1972, 2000), militaries are just one of many policy areas for which governments are responsible. Furthermore, this change in government priorities also reacts to social and political value changes which turn into electoral constraints (Edmunds, 2006). Finally, the third driver is the socio-technological adaptations that we see in applied operational contexts challenging traditional platforms, forcing militaries to rethink force, mass and space. As Farrell et al (2013) suggest, there is a constant tension between the ever-changing adversarial relationship with the enemy and the resources that a military actually maintains.

There are other drivers at play. One of the most significant has been the changing nature of the Trans-Atlantic Alliance. This has three over-arching explanations. First, NATO has both enlarged and expanded geographically from its 12 founding members to a current membership of 29 states stretching much further east than during the Cold War. Second, NATO - or NATO member states acting in coalitions of the willing - have conducted military operations from Bosnia and then Kosovo, to Afghanistan and Iraq (though the latter not a NATO operation itself), to off the coast of Somalia and Libya. For some, like Stuart Croft et al (2000), operations have given NATO a new lease and as we will see, they have also been a key driver of innovation for many European states. Finally, we have the US's changing relationship with Europe, from 'pivots' to 'resets' and there is uncertainty about what the medium to long term strategy is for the US government and where the transatlantic partnership fits into that. This uncertainty has only increased under the Trump Administration since 2017. Nevertheless, the US remains a key transmission-belt for European military innovation, perhaps even more so than European governments themselves.

The explanatory logic contained in the four models outlined above has been evident in European innovation since the Cold War. This literature is distinctly layered whereby military innovation and transformation is driven by state interest that is filtered through various external threat perceptions, attitudes towards alliance politics, domestic political-social agendas, and/or combat-operational necessities. In the immediate post-Cold War era, European governments welcomed the so-called 'peace dividend' and their militaries have been shaped less by existential threats posed by great powers as the context of European security changed to making and keeping the peace, to fighting the 'war on terror'. At the same time, the US was experimenting with different approaches to warfare that would attempt to build in momentum and change. European militaries have also experienced the other layered drivers, as NATO enlarged and 'transformed', as defence budgets shrank and services competed, and as European militaries found themselves in protracted but illusive combat in Afghanistan and Iraq.

However, the transformation literature fails to take into account the inter-linking between layers. Rather than seeing these drivers as distinct, we should instead see them as inter-related and reflexive whereby adaptions and innovation at the operational level may reverberate in budgets, services, alliances and even perceptions of global threats to national security. What is needed is a way that we can look at this system of military change that is able to take these linkages into account. The research project The Drivers of Military Strategic Reform in the Face of Economic Crisis and Changing Warfare, led by David Galbreath (also see: Galbreath, 2016), has suggested a one framework for accomplishing this. As a result, this chapter suggests that change can be understand across the literature in three ways, transform, transfer and translate. 
This approach assumes that militaries are always forward leaning even when path dependent and perhaps doomed to prepare for the next war in the style of the last one (see Gray, 2005). In fact, not only does competition and uncertainty drive change but organisations naturally transform, as suggested by Niklas Luhmann (2006). All of this is to say, we should expect to see change as a necessary element of transformation.

Secondly, transference entails a relocation from outside a military into said military. Typically, the transformation literature has suggested that the US and its so-called Revolution in Military Affairs (RMA) have been frames that have impacted on European militaries, whether that is network centric warfare, effects-based operations or paramilitary troops (Farrell and Rynning 2010; Galbreath 2014; 2015) or something more practical like basic military kit. More often though, transfer happens through socialization. In their studies of military transformation, Theo Farrell et al (2010) and Ina Wiesner (2013) suggest that transformation often happens as a result of communication between officers from different militaries, in particular at officer training in the US. Reporting those responsible for platforms like networked enabledness, there is evidence that some innovations or adaptations are in fact learned, especially when they are within the context of a notion or system of war. At the same time, there is often such a dependence on deploying with US forces, that there needs to be a way in which European armed forces can 'plug-in' to US forces without making either less battle-ready (see Rasmussen 2013). This dilemma fits into the capabilities gap that has arisen between US and European forces since the end of the Cold War (see Coonen 2006). However, we should allow for the possibility that European to European transfer may be even more relevant than that between the US and a European military. Although we can expect that the majority of original innovation would be located in a military that is more resourced and diverse like the US military, this does not mean to suggest that European forces cannot be the source of innovation as well.

Finally, we can think of military change through the concept of translation. Already, we understand that while European states may share some basic, and perhaps even advanced, notions of war with US forces, we also can see that European states have different military traditions and strategic cultures that shape the way they think about deployment and operations. In fact, it is difficult to find a direct transfer from one military to another. Nearly 70 years of NATO suggests that the translation between the US and European militaries should be gradually less over time, but this does not take into account either how resourced and large the US military is nor does it take into account the changes in European social values towards standing armies since the end of the Cold War. The RMA was translated to Europe, through joint deployments, NATO Allied Command Transformation (ACT) and its impact on US and European defence industries. Network Centric Warfare, perhaps a major characterization of RMA, has been translated however in various different ways in Europe as a result of cultural and resources conditions. Cultural and resource conditions are difficult to separate in as far as states will seek to resource what they find strategically and culturally important. Of the three explanations of change, translation is arguably the most useful in explaining military innovation in Europe.

In summary, transform, transfer and translate can be understand to work across the multiple levels of change established in the innovation literature review section above. With transfer and translate concentrating on the role of social communication and learning, we should not forget that there are endogenous reasons why transformation may occur, such as to reduce or increase the number frigates, tanks, combat soldiers, establish joint command and operations, 
etc. Overall, we think that endogenous and exogenous factors are fundamental to understanding changes in European militaries. To add another dimension to our analysis, let us now unpack changes in European militaries through Galbreath's three additional categories of followship, frontline and falling (Galbreath, 2016).

\section{Case Studies in European Defence Innovation}

Galbreath's three groupings offer an indication of the direction of change within and across European militaries. Followship is change that results from a close following of other militaries which is an accepted and understood role between follower and the leader, very often the United States. Secondly, frontline refers to those militaries that have experienced change as a result of combat operations. Finally, there are those militaries and capabilities that are falling behind due to falling budgets and falling strategic value. Combining transform, transfer and translate with followship, frontline and falling offers a multi-level set of explanations to assess European defence innovation comprehensively.

European militaries have been changing in a variety of different ways since the end of the Cold War. For the most part, the number and role of the combat soldier has lessened even though both Afghanistan and Iraq have had a major land warfare component. The reduction in combat and support soldiers across land, sea and air services is also reflected in military capabilities as governments were determined to fund fewer platforms, such as tank battalions, frigates, and heavy lift aircraft. While the wars of the 'War on Terror' have boosted certain elements of European militaries, the general direction of military spending on personnel and platforms has continued to decline with few exceptions (c.f. Poland). Combining this decline with modern warfare as a largely asymmetric, multidimensional affair, militaries have also been seeking to work jointly across services. In his major contribution, The Transformation of Europe's Armed Forces, Anthony King argues that there is a 'fundamental dynamic' at play with European militaries whereby they are undergoing a 'simultaneous process of concentration and transnationalisation' (King, 2011: 11). According to King (2011: 17), European armed forces are:

undergoing a compatible but differentiated process of
'glocalisation'. They are concentrating at decisive locales from
which they are extending out increasingly deep institutional
relations to produce a new military order of multiple,
interdependent nodes and interconnected transnational
networks.

Jointness has also become a major part of contemporary military command and operations. In the UK, the 2010 Strategic Defence and Security Review (SDSR) determined that joint budget arrangements for operations and kit would need to be inter-service procured and managed. A joint- command structure makes this easier to accomplish in theory. The experience in working in Afghan Provincial Reconstruction Teams (PRTs) has also led European militaries to think about doing more in theatre with less. As a result, Sapolsky's $(1972,2000)$ notion of a bureaucratic politics explanation of innovation becomes challenged as jointness appears to obscure the politics behind the change.

Finally, as a result of an evolving and complex threat environment, one whereby the conceptual clarity between defence and security has blurred, defence budgets continued to shrink but security budgets continue to rise. Militaries have a role to play in traditional and new forms of security while at the same time militaries have the incentive to compete for budgets in new and 
well-funded policy areas. While this has the potential to militarise those new policy areas, this situation also provides an opportunity to transform European militaries. The result is a combined approach to security challenges. Contemporary military operations are likely to be the results of joint commands with increasingly combined roles for civilian departments and agencies. This change, along with reduced budgets, pose different challenges for our three groups of states within the followship, frontline and falling categories.

\section{Followship}

The most advanced, and predominantly largest militaries fall into this category; in particular, the UK, France, Germany and Poland. None of these militaries are seeking to exponentially increase their defence capabilities and are only meeting (although not in the case of Germany) the NATO guideline to spend a minimum of $2 \%$ of their Gross Domestic Product (GDP) on defence (North Atlantic Council, 2014). At the same time, they are in the forefront of military transformation in Europe. Yet, how they are changing is different, partly because the US is the 'model army' but also because they have little experience of actually working with each other on the ground; even if they did contribute to the same NATO ISAF mission in Afghanistan for example. Few common lessons are being learned and internalised due to different national priorities and different national constraints. At the same time, there are serious financial constraints challenging innovation for these militaries as well.

Though finances are a theme throughout European defence, these states are more serious about maintaining modern militaries with the prospect of using them in the future. France and the UK have the most advanced and operationally capable militaries in Europe. They have both responded to the advances in military concepts and technologies in similar ways. Both states have sought to incorporate networked-enabled concepts and technology into their existing operational plans and future procurement. The British military has innovated in response to a changing external threat environment post-Cold War but this has seen them return to their traditional posture as an expeditionary-oriented force. The US has been the leading transmission belt for this innovation through its exporting of the RMA and by setting the operational agenda over the last 25 years. But this transferring of US innovation has also been translated and shaped by two 'domestic factors', constraints on military resources and a distinct British military culture (Farrell and Bird in Terriff et al, 2010: 56).

The French military has also innovated and transformed in response to 'strategic and technological changes' with the US as the primary external source of innovation (Farrell et al, 2013: 277) But they too have sought to translate this innovation to suit their own interests, threat perceptions and operational needs. German innovation has not been driven by geostrategic factors in the main and the biggest challenge has been the political and domestic security culture surrounding the use and the purpose of military force. Although transformation has clearly been evident. The German military has innovated its capabilities, doctrine and even its operational thresholds. Poland's transformation since the end of the Cold War has been both in the realm of capabilities, concepts and doctrine but it also had to introduce 'civilian and democratic controls' (Oscia in Terriff et al, 2010: 167).

For all four states, there has been concern about the state and future of their land forces. The reduction in the number of those serving has declined and is planned to further decline while the remaining soldiers in both armies are to be more operationally effective across a wide spectrum of possible deployments. By and large, this group of countries are the strongest European followers of the US broader way of war, though with much less capability and 
capacity than their US counterparts. These armed forces in these states, to varying degrees, are active followers and play a significant and perhaps defining role in European defence.

\section{Frontline}

Some militaries find that their ability to innovate is limited to when they are on the frontline. In this group are European states such as Italy, Spain, the Netherlands, Norway, and Denmark. These states have arguably experienced the most in terms of decline in the number of personnel and platforms following the end of Cold War. They were militaries designed largely and predominantly for NATO's territorial defence against a possible Soviet invasion and not for the expeditionary conflicts of the sort we have seen in the last 20 years. Their evolution from conscription-based militaries to all volunteer forces (AVFs) has also played a major role in this reduction in capacity. Further, these countries took participating in the Afghan and Iraq wars to invest in modernizing their forces. As a result, by eliminating (or suspending) national service and reducing the number of voluntary enlisted, they drastically reduced their combat effectiveness on the ground while continuing to invest in their air power platforms. Thus, the key drivers of change in these states have been their simultaneous transformation to AVF with limited expeditionary capability via interventionist wars in the Middle-East and North Africa.

Italy, being the largest, has the most to gain from what is happening in the 'following' states, though Italy (like Spain and further Greece) has had its transformation project curtailed by the global financial crisis. Spain, having begun its transformation during the centre-right government of José María Aznar, sought to transform its expeditionary and peacekeeping troops through ISAF and EU Common Security and Defence Policy (CSDP) missions. The Netherlands has also played an important role in Central Afghanistan and has maintained a combat ready ground force that was able to work with the US and UK especially in developing COIN capabilities during Task Force Uruzgan. As such, NATO has played a central role in shaping Dutch military innovation. The Dutch have also gone further in its naval cooperation with Belgium via the so-called Benesam arrangement whereby the two nations have integrated command, training and basing for frigates and mine hunters in order to maintain an active naval capacity.

Finally, Norway and Denmark have both come out of Afghanistan with a clear direction for their militaries and in particular their armies. Norway, has sought to bolster its northern borders and economic interests with new battalions, a doctrine it is familiar with from its time as being one of two NATO member countries with a border with the Soviet Union. Due to its sizable commitment in Afghanistan, Denmark has also developed a more directed doctrine of transforming to work directly with the US. They have determined that their strategic interests lie with being able to integrate with US forces to the detriment of being able to operate alone or with other European states. For all of these states, a frontline was an important modernizer for their militaries, especially their armies. However, beyond a front line or a resurgent Russia, there is a limited scope or even ability to look for innovation and transformation in the way understood in the bigger European military states.

\section{Falling}

Although national military organisations do not always want to acknowledge that some "core tasks' of their military business can no longer be achieved, for others this Rubicon has already been crossed (Galbreath and Smith, 2016: 193-94). In this category are European countries 
which are just simply disinvesting in their militaries as a matter of political choice. Namely, countries like Belgium, Austria and Sweden have militaries that are increasingly designed for deployment in multinational peacekeeping operations rather than for territorial defence; although they do remain under the US nuclear umbrella.

For European states like Belgium, the main driver of force transformation and reform is a lack of resources. Rather than being uniquely related to defence policy, these militaries essentially become an extension of foreign policy. Although they retain very limited military capacity, they still attempt to demonstrate their utility to allies and partners by contributing an air squadron or some personnel to a NATO, EU or coalition crisis management or peace-keeping operation (please see Section Two, chapters 4 and 6 of this book). Naturally, especially in the case of Sweden and Austria, there are historical and political reasons why the military may be relegated, the further we move away from the Cold War.

\section{Conclusion.}

This chapter has described historical approaches as well as state-of-the-art theories for explaining military innovation generally and with regard to European defence specifically. It has sought to give the reader an understanding of the type of questions and challenges that scholars of military innovation have grappled with over the last century (see Table 1). The first section teased out some of the larger themes that strategists and scholars have derived from studying how militaries operate, both as organisations conducting and preparing for combat operations. These themes have ranged from attempting to understand the character of the next war to a realization that military organisations often learn different (often wrong) lessons from the same wars. How the external threat environment is perceived combined with the inevitable competition between various distinctive 'advocates' of innovation is what drives change in defence organisations.

From the work of Barry Posen to Theo Farrell, we have seen how the study of defence innovation has assumed a destinct social-science methodology since the early 1980s. Four models of innovation were defined (see Table 2). The logics in these approaches portray innovation as deriving from civil-military dynamics, to variations of interservice rivalry and intraservice competition over scarce resources. Finally, we have seen that military culture is also a key driver of, or restraint on, defence innovation. An analytical framework to cut across these literatures of transformation was then provided before turning that framework on the specificity of European defence innovation. It suggested that change can be understood via the concepts of transform, transfer and translate and that European states tend to fall into the categories of followship, frontline, and falling. There are clearly challenges facing all European armed forces - not least of all declining budgets and personnel. Yet, there is a demonstrable shift occurring in both the global and regional political-security atmosphere. It is difficult to predict what the future operating environment or the shifting security architecture in Europe may bring. But change is the only constant in life and, therefore, some form of innovation is inevitable.

Further Reading:

- Coker, C., 2015. Future War. Polity, Cambridge. 
- Farrell, T., Rynning, S., Terriff, T., 2013. Transforming Military Power since the Cold War: Britain, France, and the United States, 1991-2012. Cambridge University Press, New York.

- Freedman, L., 2017. The Future of War: A History, 1 edition. PublicAffairs, New York.

- Galbreath, David J. 2014. 'Western European Armed Forces and the Modernisation Agenda: Following or Falling Behind?’ Defence Studies 14 (4): 394-413.

- Grissom, A., 2006. 'The Future of Military Innovation Studies', The Journal of Strategic Studies. 29, 905-934.

- King, A., 2011. The Transformation of Europe's Armed Forces: From the Rhine to Afghanistan. Cambridge University Press, Cambridge; New York.

Web links:

- Development, Concepts and Doctrine Centre (DCDC): https://www.gov.uk/government/groups/development-concepts-and-doctrine-centre

- The French Institute for International and Strategic Affairs: http://www.irisfrance.org/en/

- Royal United Services Institute: https://rusi.org/

- DARPA: https://www.darpa.mil/

- NATO Allied Command Transformation: https://www.act.nato.int/

- European Defence Agency: https://www.eda.europa.eu/

- RAND research on military transformation: https://www.rand.org/topics/militarytransformation.html

- War on the Rocks: https://warontherocks.com/

\section{Bibliography}

Bacevich, A.J., 1986. The Pentomic Era: The U.S. Army Between Korea and Vietnam. National Defense University Press, Washington DC.

Clausewitz, C.V., 1997. On War, Abridged edition. ed. Wordsworth Editions.

Coonen, S. J.; 2006. 'The Widening Military Capabilities Gap between the United States and Europe: Does It Matter?', Parameters 36: 67-84.

Cote, O.R., 1998. The Politics of Innovative Military Doctrine: The U.S. Navy and Fleet Ballistic Missiles. MIT, Cambridge, MA.

Croft, S., et al. 2000., 'NATO’s Triple Challenge.', International Affairs 76: 495-518.

Edmunds, T,. 2006. 'What Are Armed Forces for? The Changing Nature of Military Roles in Europe.', International Affairs 82 (6): 1059-75.

Farrell, T., and Rynning, S., 2010. 'NATO's Transformation Gaps: Transatlantic Differences and the War in Afghanistan.', Journal of Strategic Studies 33 (5): 673-99.

Farrell, T., Rynning, S., Terriff, T., 2013. Transforming Military Power since the Cold War: Britain, France, and the United States, 1991-2012. Cambridge University Press, New York. 
Farrell, T., Terriff, T. (Eds.), 2001. The Sources of Military Change: Culture, Politics, Technology. Lynne Rienner Publishers, Boulder, Colorado.

Galbreath, D. J., 2016. 'Understanding changes in European militaries: a system approach'. Presented at the Annual Convention of the International Studies Association, Atlanta, Georgia, USA, 15-18 March 2016.

Galbreath, D.J, and Smith, S.J, 2016. 'Military Capabilities and Force Transformation' in Chappell, L., Mawdsley, J., Petrov, P. (Eds.), 2016. The EU, Strategy and Security Policy: Regional and Strategic Challenges. Routledge, London.

Galbreath, D.J., 2014. 'Western European Armed Forces and the Modernisation Agenda: Following or Falling Behind?', Defence Studies 14 (4): 394-413.

Galbreath, D.J., 2015. 'RMA, European Militaries and the Limits of Modernization.', in Reassessing the Revolution in Military Affairs: Transformation, Evolution and Lessons Learnt, 156-74. Basingstoke: Palgrave Macmillan.

Gray, C.S., 2005. 'How Has War Changed Since the End of the Cold War?', Parameters 35: $14-26$.

Grissom, A., 2006. 'The Future of Military Innovation Studies.', The Journal of Strategic Studies. 29, 905-934.

Horowitz, M.C., 2010. The Diffusion of Military Power: Causes and Consequences for International Politics. Princeton University Press, Princeton, N.J.

King, A., 2011. The Transformation of Europe's Armed Forces: From the Rhine to Afghanistan. Cambridge University Press, Cambridge ; New York.

Luhmann, Niklas. 2006. "System as Difference.” Organization 13 (1): 37-57.

Mewett, C., 2014. Understanding War's Enduring Nature Alongside its Changing Character War on the Rocks. Available from: https://warontherocks.com/2014/01/understanding-warsenduring-nature-alongside-its-changing-character/ (accessed 5.11.18).

North Atlantic Council (2014) NATO Wales Summit Declaration. Available from: https://www.nato.int/cps/en/natohq/official texts 112964.htm (accessed 15.10.18)

Posen, B., 1984. The sources of military doctrine: France, Britain, and Germany between the world wars. Cornell University Press, Ithaca.

Rasmussen, M.V., 2013. 'The Military Metier: Second Order Adaptation and the Danish Experience in Task Force Helmand.' in Military Adaptation in Afghanistan, edited by Theo Farrell, Frans P. B. Osinga, and James A. Russell. Stanford, California: Stanford University Press.

Rosen, S.P., 1988. 'New Ways of War: Understanding Military Innovation.', International Security 13 (1): 134-68. 
Rosen, S.P., 1994. Winning the Next War: Innovation and the Modern Military, 1st edition. Cornell University Press, Ithaca, NY London.

Sapolsky, H.M., 1972. The Polaris System Development: Bureaucratic and Programmatic Success in Government. Harvard, Mass.: Harvard University Press.

Sapolsky, H.M., 2000. 'On the Theory of Military Innovation'. Breakthroughs 9, 35-39. Terriff, T., Osinga, F., Farrell, T., (Eds.), 2010. A Transformation Gap: American Innovations and European Military Change. Stanford Security Studies, Stanford, Ca.

Wiesner, I., 2013. Importing the American Way of War?: Network-Centric Warfare in the UK and Germany. Baden-Baden: Nomos Publishers. 